\title{
ESTUDIO DEL IMPACTO DE LA ACTIVIDAD APÍCOLA EN EL ISTMO DE TEHUANTEPEC, OAXACA, MÉXICO
}

\author{
IMPACT EVALUATION OF APICULTURE ACTIVITY IN THE TEHUANTEPEC \\ ISTHMUS, OAXACA, MÉXICO
}

Guillermo Dolores-Mijangos ${ }^{1}$, Ma. de Jesús Santiago-Cruz ${ }^{2}$, J. Jaime Arana-Coronado ${ }^{2}$, Fernando Utrera-Quintana ${ }^{3^{*}}$

\begin{abstract}
1Postgrado de Socioeconomía, Estadística e Informática-Economía, (guillermo.dolores@colpos. $\mathrm{mx})$, ${ }^{2}$ Postgrado de Socioeconomía, Estadística e Informática-Economía. Campus Montecillo. Colegio de Postgraduados. Km 36.5 Carretera México-Texcoco. Montecillo, Estado de México. C.P. 56230. (ecomjsc@colpos.mx) (coronado.jarana@colpos.mx), 35Facultad de Medicina Veterinaria y Zootecnia-BUAP, Carretera Cañada Morelos km 7.5, El Salado Tecamachalco Puebla (fernando. utrera@correo.buap.mx)
\end{abstract}

\section{RESUMEN}

En la presente investigación se analiza la factibilidad de que la apicultura, como actividad complementaria de la unidad familiar genere ingresos adicionales en las unidades rurales de producción agropecuaria de la Región del Istmo de Tehuantepec. El estudio se realizó en los municipios de: Matías Romero Avendańo, El Barrio de la Soledad, San Juan Guichicovi y Chahuites, con un total de 24 encuestas, y tiene un enfoque cuantitativo y cualitativo. Se apoyó en trabajo de gabinete y trabajo de campo, este último realizado en el mes de agosto de 2013. Los resultados indican que la explotación apícola es una forma pertinente de diversificar el ingreso, dado que además de generar empleo en tiempos de menor actividad en las actividades agrícolas es rentable y constituye una opción para las unidades de producción rural, en especial para las más pequeńas. En los escenarios analizados pudo constatarse que lo invertido en la actividad supera la recuperación de una inversión equivalente en pagarés de renta fija.

Palabras clave: apicultura, diversificación del ingreso, rentabilidad, unidad de producción rural.

\section{INTRODUCCIÓN}

$\mathrm{E}$ n la presente investigación se analiza la factibilidad de que la apicultura, sea una actividad complementaria y que genere ingresos adicionales en las unidades rurales de producción agropecuaria, de la Región del Istmo de Tehuantepec.

* Autor responsable * Author for correspondence.

Recibido: septiembre, 2014. Aprobado: noviembre, 2016. Publicado como ARTÍCULO en ASyD 14: 187-203. 2017.

\section{Abstract}

In this study, the feasibility of apiculture as a complementary activity for the family unit to generate additional income in the agricultural and livestock rural production units of the region of the Tehuantepec Isthmus is analyzed. The study was carried out in the municipalities of: Matías Romero Avendańo, El Barrio de la Soledad, San Juan Guichicovi and Chahuites, with a total of 24 surveys, and has a quantitative and qualitative approach. It was supported by office work and field work, the latter carried out in the month of August, 2013. The results indicate that honey making is a pertinent way to diversify the income, given that in addition to generating employment at times of less activity in the agricultural activities, it is profitable and constitutes an option for the rural production units, especially the smallest ones. In the scenarios analyzed, it could be validated that what was invested in the activity exceeds the recuperation of an equivalent investment in promissory notes of fixed rent.

Key words: apiculture, income diversification, profitability, rural production unit.

\section{INTRODUCTION}

$\mathrm{I}$ $\mathrm{n}$ this study, the feasibility for apiculture to become a complementary activity that generates additional income for the agricultural and livestock rural production units in the region of the Tehuantepec Isthmus, is analyzed.

According to the National Statistics and Geography Institute (Instituto Nacional de Estadística y Geografía, INEGI, 2013), a secondary activity "is one that is developed within the same production 
De acuerdo con el Instituto Nacional de Estadística y Geografía (INEGI, 2013) una actividad secundaria "es aquella que se desarrolla dentro de una misma unidad de producción en adición con la actividad principal muestra un valor agregado menor al de la actividad principal y su producción genera un producto secundario que, al igual que el de la actividad principal, tiene que ser suministrada fuera de la unidad de producción".

La región con mayor producción de miel en México es la península de Yucatán, que comprende los estados de Yucatán, Quintana Roo y Campeche, sumando un total de 17014 toneladas anuales, con un valor de $\$ 477072$ miles de pesos (Sistema de Información Agroalimentaria y Pesquera, 2013).

Además de las áreas mencionadas en México existen otras que no están aprovechadas en su totalidad y donde es posible desarrollar la apicultura, como es el caso de la región del Istmo de Tehuantepec, Oaxaca, debido a que cuenta con riqueza de sus recursos naturales y los procesos de desarrollo inducido del trópico húmedo han hecho del Istmo de Tehuantepec una de las regiones más importantes. Su sistema de cuencas incluye parte de los ríos más caudalosos de México, como el Papaloapan, el Coatzacoalcos, el GrijalvaUsumacinta, los que desembocan en el Sistema Lagunar Huave y el Tehuantepec, lo que hace de esta una de las regiones más húmedas de México, lo cual explica el temprano florecimiento cultural, la riqueza de sus bosques, selvas y costas y, nuevamente, su importancia estratégica para la vida (Gómez, 2005).

Con un séptimo lugar a nivel nacional, Oaxaca cuenta con 108659 mil colmenas que representan un $4.2 \%$ para este estudio, con 24 productores y un total de 4600 colmenas, y su importancia económica a nivel nacional tiene el sexto lugar con una producción al año de 3 mil 798 toneladas de miel, a un precio de 36.64, generando \$139158 720.00 M.N en 2013 (SIAP, 2013).

Actualmente la apicultura se ubica entre los tres primeros lugares en el sector pecuario como generadora de divisas, con una derrama económica que beneficia principalmente a pequeños productores. En la península de Yucatán es posible observar cómo la miel ha generado una industria familiar que contribuye al arraigo de la familia campesina en sus lugares de origen y evitar la migración por falta de trabajo (Martínez, 2010). México se ha mantenido como el tercer exportador de miel en el mundo; en 2013 alcanzó la cifra unit in addition to the main activity showing an added value lower than that of the main activity, and its production generates a secondary product which, just as the main activity, has to be supplied outside of the production unit".

The region with highest honey production in México is the Yucatán Peninsula, which includes the states of Yucatán, Quintana Roo and Campeche, adding up to a total of 17014 tons annually, with a value of $\$ 477072$ thousand pesos (Sistema de Información Agroalimentaria y Pesquera, 2013).

In addition to the areas mentioned, in México there are others that are not being taken advantage of entirely and where it is possible to develop apiculture, as is the case of the region of the Tehuantepec Isthmus, Oaxaca, because it has wealth from its natural resources and the development processes induced in the moist tropics have made the Tehuantepec Isthmus one of the most important regions. Its watershed system includes part of the widest rivers in México, such as the Papaloapan, Coatzacoalcos, and Grijalva-Usumacinta, which flow into the Huave Lagoon System and the Tehuantepec, making this one of the most humid regions in México, which explains the early cultural emergence, the wealth of its forests, rainforests and coasts, and, again, its strategic importance for life (Gómez, 2005).

With the seventh place in the country, Oaxaca has 108659 thousand beehives that represent $4.2 \%$ for this study, with 24 producers and a total of 4600 hives, and their economic importance at the national level is sixth place with a yearly production of 3 thousand 798 tons of honey, at a price of 36.64 , generating $\$ 139$ 158720.00 pesos in 2013 (SIAP, 2013).

Currently, apiculture is among the first three places in the livestock sector as a currency generator, with an economic spill that benefits mostly small-scale producers. In the Yucatán Peninsula it is possible to see how honey has generated a family industry that contributes to the peasant families rooting themselves in their places of origin and preventing migration from lack of work (Martínez, 2010). México has remained as the third honey exporter in the world; in 2013 it reached the figure of 33 thousand 476 tons of honey, according to data from the Ministry of Economy (Secretaria de Economia, SE), with a commercial value of $\$ 112.5$ million USD from honey exports (SAGARPA, 2014). This proves that it is an important source of currency for the country. 
de 33 mil 476 toneladas de miel, según datos de la Secretaría de Economía (SE), con un valor comercial de 112.5 millones de USD por concepto de exportación de miel (SAGARPA, 2014). Esto demuestra que es una fuente importante de divisas para el país.

La apicultura es una de las actividades que maneja de manera sostenible los recursos naturales de una región y requiere relativamente poca inversión, además de que provee un ingreso importante que contribuye a la estabilidad económica en la vida de los productores (Cajero, 2004).

Por otra parte, la trascendencia social de la apicultura en México se observa en la oportunidad de producción e ingresos y en la generación de empleos. En 2013 existían 1933105 colmenas, con un rendimiento estimado de $28.6 \mathrm{~kg}$ a $31.72 \mathrm{~kg}$ por colmena de acuerdo con SAGARPA (2001), con un precio de venta de $\$ 38.11 \mathrm{~kg}^{-1}$ (SIAP, 2013). En dicho año se generó un ingreso de 2168879 millones de pesos, valor que representa el impulso a las economías locales y que inciden en el ingreso de las familias. El segundo aspecto social de interés lo evidencian los 2.2 millones de jornadas laborales que genera la apicultura al año (64.7 jornadas por apiario) y el pago por salarios de 263 millones de pesos. Así, el ingreso por venta de miel, los salarios y el valor de la compra de insumos, equipos y materiales son los principales rubros del efecto multiplicador del ingreso que genera esta actividad sobre la localidad o región del país (Magaña et al., 2012). Ello permite evitar migración, desempleo y generar ingresos a las unidades de producción.

Ante el reto del Estado mexicano y de organismos internacionales de disminuir la pobreza y no lograr resultados favorables surge la pregunta: ¿Qué alternativas tienen las familias que viven en el área rural para disminuir la pobreza? Yúnez y Taylor (2001) han mencionado que el desarrollo de actividades complementarias como una alternativa para generar ingresos extra en la unidad de producción rural surge como una estrategia de combate a la pobreza extrema; estos son mecanismos que han adoptado las familias por sí solas para complementar ingresos familiares. Muchos de los estudios sobre diversificación en las explotaciones agrarias se preguntan las razones que impulsan este proceso. Normalmente la diversificación se presenta como una estrategia de ajuste frente a las dificultades a las que se enfrenta en la unidad de producción familiar (Bowler et al., 1996).
Apiculture is one of the activities that presents sustainable management of natural resources from a region and requires a relatively small investment, in addition to providing an important income that contributes to the economic stability of producers' lives (Cajero, 2004).

On the other hand, the social transcendence of apiculture in México is seen in the opportunity of production and income and in employment generation. In 2013, there were 1933105 beehives, with an estimated yield of $28.6 \mathrm{~kg}$ to $31.72 \mathrm{~kg}$ per beehive according to SAGARPA (2001), with a sales price of $\$ 38.11 \mathrm{~kg}^{-1}$ (SIAP, 2013). In that year, an income of 2168879 million pesos was generated, value that represents the drive of local economies and which influence the families' income. The second aspect of social interest is evidenced by the 2.2 million workdays that apiculture generates per year (64.7 work days per apiary) and the payment of salaries of 263 million pesos. Thus, the income from honey sales, the salaries and the value of the purchase of inputs, equipment and materials are the main areas of the multiplying effect of the income that this activity generates on the locality or region of the country (Magaña et al., 2012). This allows avoiding migration, unemployment, and generating income for the production units.

Facing the challenge that the Mexican State and international organizations have of decreasing poverty and not achieving favorable results, the following question emerges: What alternatives do families that live in the rural area have to decrease poverty? Yúnez and Taylor (2001) have mentioned that the development of complementary activities as an alternative to generate extra income in the rural production unit arises as a strategy to combat extreme poverty; these are mechanisms that the families have adopted on their own to complement family income. Many of the studies about diversification in farms question the reasons that foster this process. Normally the diversification is presented as an adjustment strategy in front of the difficulties that the family production unit faces (Bowler et al., 1996).

Poverty is a problem that seems to have a permanent character in Mexican society. According to CONEVAL (2012), in 201216.7 million people were in rural poverty, representing $61.6 \%$ of the total population. De Janvry and Sadoulet (2004) report that the concentration of extreme poverty 
La pobreza es un problema que parece tener un carácter permanente en la sociedad mexicana. De acuerdo con CONEVAL (2012), en 2012 la pobreza rural fue de 16.7 millones de personas, lo que representa $61.6 \%$ de la población total. De Janvry y Sadoulet (2004) reportan que la concentración extrema de pobreza se da en las áreas rurales y la creciente desigualdad en la distribución de los ingresos son resultados muy preocupantes a pesar de los esfuerzos emprendidos, con frecuencia costosos, por combatir la pobreza rural y la desigualdad. Así, por ejemplo, la pobreza aumentó entre 2008 y 2012 en 3.8 millones de personas y, por otra parte, el $10 \%$ más rico de la población gana 31.8 veces lo que gana el $10 \%$ más pobre (CONEVAL, 2012).

\section{Marco Teórico}

La diversificación del ingreso permite complementar el ingreso corriente con uno extraordinario para hacer frente a los bajos ingresos y a la desigualdad, así como para mitigar sus efectos (López et al., 2011). La diversificación del ingreso puede considerarse como una estrategia de sustento de los hogares con varias actividades para generar una corriente de beneficios. En su vida cotidiana las familias implementan indirectamente la diversificación del ingreso, ya que lo visualizan como alternativa para aportar recursos a sus economías.

Existen dos vertientes por las cuales la diversificación del ingreso/productiva se ve como una alternativa para los integrantes de una familia (Yúnez y Taylor, 2001). Las razones por las cuales los hogares se diversifican pueden ser explicadas de manera simple por dos motivos: por necesidad (push factors) o por opción (pull factors). En el primer caso la diversificación se da como una respuesta a la crisis del sector agropecuario, al alza de los precios agrícolas, a la disminución del ingreso, al riesgo por cambios climáticos, por los altos costos de transacción, o como una estrategia de combate a la pobreza extrema. En el segundo caso, la diversificación es una opción para acceder a nuevos mercados, a mercados específicos, o como una estrategia económica para complementar el ingreso. Ante las dos situaciones antes mencionadas las familias en México adoptan estrategias de ingresos para solventar gastos de primera necesidad; esto implica que alguno de los miembros de la familia podría estar empleado o laborando en actividades no agropecuarias o agropecuarias (Hazael, 2012).

Pellens (2006) analiza específicamente la diversificación agrícola como estrategia para aprovechar de takes place in rural areas and the growing inequality in the distribution of income are quite worrisome results despite the efforts undertaken, frequently costly, to combat rural poverty and inequality. Thus, for example, poverty increased between 2008 and 2012 in 3.8 million people and, on the other hand, the richest $10 \%$ of the population earns 31.8 times what the poorest $10 \%$ earns (CONEVAL, 2012).

\section{Theoretical Framework}

The diversification of incomeallows complementing the current income with an extraordinary one to face the low income and inequality, as well as to mitigate their effects (López et al., 2011). The diversification of income can be considered a strategy of household sustenance with several activities to generate a current of benefits. In their daily life the families implement the diversification of income indirectly, since they visualize it as an alternative to contribute resources to their economies.

There are two aspects for which the incomel productive diversification is considered an alternative for the members of a family (Yúnez and Taylor, 2001). The reasons why the households are diversified can be explained simply by two causes: the need (push factors) or the option (pull factors). In the first case the diversification takes place as a response to the crisis of the agricultural and livestock sector, the increase of agricultural prices, the decrease of income, the risk from climate changes, the high transaction costs, or as a strategy to combat extreme poverty. In the second case, the diversification is an option to gain access to new markets, specific markets, or as an economic strategy to complement the income. In face of these two situations mentioned before, the families in México adopt income strategies to afford the expenses of basic necessities; this implies that some of the members of the family could be employed or working in non-agricultural/livestock, or agricultural/livestock activities (Hazael, 2012).

Pellens (2006) analyzes specifically agricultural diversification as a strategy to take advantage of the available resources in a better way; for this purpose, the restrictions and possibilities of the ecological environment are taken into account, and of ensuring the family diet now and in the future.

One of the variables is the conditions of the ecosystem present in the agricultural zones that 
mejor manera los recursos disponibles; para ello se toman en cuenta las restricciones y posibilidades del entorno ecológico, y de asegurar la dieta alimentaría familiar ahora y en el futuro.

Una de las variables son las condiciones del ecosistema presente en las zonas agrícolas que influyen de varias maneras en el grado y la forma de diversificación. Primero, las características climáticas, ecológicas y orográficas condicionan en gran medida los cultivos potenciales a producir $y$, consecuentemente, la diversificación potencial del sistema agrícola (Pellens, 2006). En el Istmo de Tehuantepec sobreviven los bosques y las selvas tropicales húmedas más importantes del país por su biodiversidad y extensión conservada (Chimalapas, Uxpanapa, Mixe baja). Esta gran zona de contacto entre la fauna y la flora de Norte y Sudamérica forma parte del grupo de ecosistemas que albergan todavía entre 30 y $40 \%$ de la biodiversidad del Planeta (García, 1998).

Valdivia et al. (1996) mencionan que el alto grado de estacionalidad en la agricultura, consecuencia entre otros de los ciclos en el ecosistema, motiva la diversificación de cultivos, ya que así la familia puede optimizar el uso de los recursos productivos del hogar durante todo el año. Esta característica posibilita a los productores a generar otros ingresos mediante diferentes actividades.

\section{La apicultura como actividad complementaria}

La actividad complementaria es el conjunto de ocupaciones dirigidas a desarrollar fuentes de ingresos diferentes a las provenientes de la explotación agrícola propia, ya sea como ingreso principal o secundario. Este conjunto comprende entonces las actividades que tienen lugar fuera de la explotación, cualquiera que sea el sector de actividad (agrícola o no agrícola) y las no agrícolas que tienen lugar en la explotación (Phélinas, 2002).

Por otra parte, si bien existen otros conceptos ligados a las actividades complementarias, y esta es la diversificación de las actividades o pluriactividad, esto se refiere a la obtención de un ingreso de más de una actividad económica. El tiempo productivo de un individuo puede utilizarse entonces de varias maneras (Phélinas, 2002), lo que significa que el individuo puede participar y desarrollar diversas actividades fructíferas; por ejemplo, participar en sociedades agrícolas o de otro tipo. influence in many ways the degree and form of diversification. First, the climate, ecological and orographic characteristics condition to a large degree the potential crops to be produced and, consequently, the potential diversification of the agricultural system (Pellens, 2006). In the Tehuantepec Isthmus the most important forests and moist rainforests of the country survive because of their biodiversity and area conserved (Chimalapas, Uxpanapa, Low Mixe). This contact zone between the fauna and flora of North and South America is part of the group of ecosystems that still house between 30 and $40 \%$ of the planet's biodiversity (García, 1998).

Valdivia et al. (1996) mention that the high degree of seasonality in agriculture, consequence among other things of the cycles of the ecosystem, motivates the diversification of crops, since this way the family can optimize the use of productive resources of the household throughout the year. This characteristic allows the producers to generate other incomes through different activities.

\section{Apiculture as a complementary activity}

The complementary activity is the group of occupations directed at developing sources of income different from those that come from the farm itself, whether as principal or secondary income. This group then includes the activities that take place outside the farm, whichever the activity sector is (agricultural or non-agricultural) and the non-agricultural ones that take place in the farm (Phélinas, 2002).

On the other hand, although there are other concepts linked to the complementary activities, and this is the diversification of activities or pluriactivity, this refers to obtaining income from more than one activity. The productive time of an individual can be used then in several ways (Phélinas, 2002), which means that the individual can participate in and develop various fruitful activities; for example, participating in agricultural societies or of another type.

Sands (1984) explains that apiculture in this region responds to a different logic from market economy, since it is not practiced to obtain large economic benefits. Echazarreta González (1999) and Villanueva and Collí Ucán (1996) agree in pointing out that it is a complementary activity along with other subsistence activities such as agriculture, backyard animal farming and forestry. 
Sands (1984) explica que la apicultura de esta región responde a una lógica diferente a la economía de mercado, ya que no se practica para obtener grandes beneficios económicos. Echazarreta González (1999) y Villanueva y Collí Ucán (1996) coinciden en señalar que es una actividad complementaria con otras de subsistencia, como la agricultura, animales de traspatio y la forestaría.

En el presente estudio la apicultura se considerará una actividad complementaria a la agrícola, desarrollada por los productores, desde el punto de vista de que permite generar ingresos adicionales que financieramente generan más beneficios que costos y que optimiza el uso de los recursos productivos, tales como el uso de la mano de obra que en ciertos periodos del año no es utilizada en su totalidad.

\section{Metodología}

En la región de estudio se seleccionó una muestra de 24 productores. En plática sostenida con el jefe de Centro de Apoyo al Desarrollo Rural de SAGARPA (CADER) se logró conocer la proporción de productores pertenecientes a cada estrato, 25-50-25 pequeño, mediano y grande, respectivamente. La muestra aplicada conservó esta proporción, quedando de la siguiente manera: pequeños, $26 \%$; medianos, $48 \%$; y Grandes, $26 \%$.

La región de estudio se encuentra localizada en el Istmo de Tehuantepec, Oaxaca. Los productores antes citados se caracterizan por tener una producción donde su principal mano de obra es familiar.

$\mathrm{La}$ investigación incluyó los municipios de El Barrio de la Soledad, Matías Romero Avendaño, San Juan Guichicovi, y Chahuites, donde hay 14 productores en el padrón de beneficiarios del Programa de Producción Pecuaria Sustentable y Ordenamiento Ganadero y Apícola que depende de la SAGARPA; a nivel estatal existen 741 registrados (PROGAM) en 2013.

El trabajo de investigación se realizó en dos fases: la de gabinete y la de campo. Los parámetros que se utilizaron fueron: descripción de la unidad familiar, equipo, insumos, manejo de la actividad, y producción. Los datos de campo se obtuvieron mediante la aplicación de encuestas directas al productor. La encuesta se diseńó previamente con un total de 24 productores quienes en conjunto disponen de 4600 colmenas con características heterogéneas. Para un
In this study apiculture is considered a complementary activity to agriculture, developed by the producers from the point of view that it allows creating additional income which generates financially more benefits than costs, and which optimizes the use of productive resources, such as the use of the workforce that in certain periods of the year is not used in its totality.

\section{Methodology}

A sample of 24 producers was selected in the study region. In a conversation held with the head of SAGARPA's Center for Rural Development Support (Centro de Apoyo al Desarrollo Rural de SAGARPA, CADER) it was possible to understand the proportion of producers that belonged to each stratum, 25-50-25, small-scale, medium-scale and large-scale, respectively. The sample applied kept this proportion, and it resulted in the following: small-scale, $26 \%$; mediumscale, $48 \%$; and large-scale, $26 \%$.

The study region is located in the Tehuantepec Isthmus, Oaxaca. The producers cited before are characterized by having a production where the main workforce is the family.

The study included the municipalities of $\mathrm{El}$ Barrio de la Soledad, Matías Romero Avendaño, San Juan Guichicovi and Chahuites, where there are 14 producers in the registry of beneficiaries of the Program for Sustainable Livestock Production and Livestock and Apiculture Zoning (Programa de Producción Pecuaria Sustentable y Ordenamiento Ganadero y Apicola) that depends on SAGARPA; at the state level there are 741 registered (PROGAM) in 2013.

The research work was carried out in two phases: office work and field work. The parameters used were: description of the family unit, equipment, inputs, management of the activity, and production. The field data were obtained through the application of surveys directly to the producer. The survey was designed previously with a total of 24 producers who together have 4600 beehives with heterogeneous characteristics. For a better study the information was organized into small, medium and large strata. In addition, the information from the producer with the highest number of beehives (1500) was eliminated because it was an atypical piece of data that distorts the statistical measurements, such 
mejor estudio la información fue organizada en estratos pequeños, medianos y grandes. Adicionalmente, se eliminó de la información la proveniente del productor con mayor número de colmenas (1500) por ser un dato atípico que distorsiona las medidas estadísticas, tales como máximos y mínimos, media, promedios, varianza, y covarianza.

El muestreo "bola de nieve" (Cuadro 1) (Mas, 2010) consistió en la selección de los productores donde se selecciona un grupo inicial de encuestados, generalmente al azar. Después de ser entrevistados se les pide que identifiquen a otros que pertenecen a la población de interés. Los encuestados subsecuentes se seleccionaron con base en sus referencias, lo que lleva a un efecto de bola de nieve en el que deben aplicarse encuestas, cubriendo la mayor parte del área geográfica bajo estudio. Para el análisis de los datos se utilizó el software Excel, 2010.

En la fase de gabinete se hizo la revisión de literatura, se diseñó un cuestionario y se delimitó un área de estudio homogénea para poder identificar las características comunes de las unidades de producción apícola. En la etapa de campo se realizaron encuestas a productores de miel de la región del Istmo de Tehuantepec con la finalidad de conocer la situación actual de la apicultura y contar con la información necesaria para analizar sus costos variables, costos fijos e ingresos.

Para el análisis de factibilidad de la apicultura se toman los siguientes indicadores:

1. Relación beneficio/costo (B/C). Esta razón indica el retorno en dinero obtenido por cada unidad monetaria invertida. Se obtiene de dividir el ingreso bruto entre el costo total. Cuando la relación es igual a 1 el productor no gana ni pierde con la inversión. Relaciones mayores a 1 indican as maximums and minimums, median, averages, variance and covariance.

The "snowball" sampling (Table 1) (Mas, 2010) consisted in the selection of the producers where an initial group of survey respondents was selected, generally randomly. After being interviewed they are asked to identify others who belong to the population of interest. The subsequent survey respondents were selected based on their references, which leads to a snowball effect in which surveys must be applied, covering the largest part of the geographical area under study. For data analysis, the Excel software 2010 was used.

In the office phase a literature review was performed, a questionnaire was designed, and a homogeneous study area was defined in order to identify the common characteristics of the honey production unit. In the field stage surveys were carried out with honey producers in the region of the Tehuantepec Isthmus with the aim of understanding the current situation of apiculture and having the information necessary to analyze its variable costs, fixed costs and incomes.

For the feasibility analysis of apiculture, the following indicators are taken:

1. Benefit/cost relation (B/C). This rate indicates the return in money obtained from each monetary unit invested. It is obtained from dividing the gross income by the total cost. When the relation is equal to 1 the producer does not win or lose with the investment. Rates higher than 1 indicate profits and lower than one indicate losses (Herrera, 1994).

For the determination of the Benefit/Cost Relation, an updating rate of $3.8 \%$ was applied,

Cuadro 1. Variable analizada: número de colmenas, global y por estrato.

Table 1. Variable analyzed: number of beehives, global and by stratum.

\begin{tabular}{lcccc}
\hline \multicolumn{1}{c}{ Estadístico } & Global & Pequeño & Mediano & Grande \\
\hline Promedio & 196.5 & 23.3 & 108.0 & 283.3 \\
Varianza & 103727.5 & 66.7 & 1195.6 & 17666.7 \\
Desviación estándar & 322.1 & 8.2 & 34.6 & 132.9 \\
Mínimo & 15 & 15 & 60 & 200 \\
Máximo & 500 & 35 & 150 & 500 \\
\hline
\end{tabular}

Fuente: elaboración propia con datos de la encuesta 2013. * Source: authors' elaboration with data from the 2013 survey. 
ganancias y menores a uno indican pérdidas (Herrera, 1994).

Para la determinación la Relación Beneficio/Costo se aplicó una tasa de actualización de $3.8 \%$, el cual es el valor promedio de la inflación 2013, Banco de México (BANXICO).

2. El punto de equilibrio. Este indicador permite entender las relaciones entre los costos fijos, los costos variables y la ganancia en el proyecto. Se define como el nivel de producción en el que los beneficios por ventas son exactamente iguales a la suma de los costos fijos y los variables.

Se realizaron las validaciones de los datos y la estandarización de los mismos. Por ejemplo, en el caso de unidades para representar la producción se definió si se expresa en volumen (litros) o en masa (kg, toneladas, por ejemplo); para este estudio la producción fue en kilogramos.

El análisis de los datos obtenidos se analizó mediante estadística descriptiva, medias, máximos, mínimos desviación estándar, frecuencias.

\section{El marco de muestreo}

Las localidades incluidas en el marco de muestreo son ocho: Las flores, Barrio Juárez, Matías Romero Avendaño, Buenavista, San José de las flores, Barrancones, Colonia Hidalgo y Chahuites. Pertenecientes a cuatro municipios del estado de Oaxaca: El Barrio de la soledad, San Juan Guichicovi, Matías Romero Avendaño y Chahuites.

\section{Definición del marco de muestreo}

Se estableció como unidad de análisis a los apicultores de la zona de estudio, agrupándolos por el número de colmenas que trabajan, dado que guarda relación directa con la forma de comercializar el producto.

$\mathrm{Al}$ identificar a los agentes y canales de comercialización se pudo observar que:

a) Los pequeños productores ( 1 a 35 colmenas) venden el producto, ellos mismos en el mercado de la región.

b) Los medianos productores (36 a 150 colmenas) utilizan dos canales para vender su producto, uno which is the average value of inflation 2013, Banco de México (BANXICO).

2. The equilibrium point. This indicator allows understanding the relationships between the fixed costs, the variable costs and the profit in the project. It is defined as the production level at which the benefits from sales are exactly equal to the sum of fixed and variable costs.

Validations of the data and their standardization were carried out. For example, in the case of units used to represent the production, it was determined whether it is expressed in volume (liters) or in mass (kg, tons, for example); for this study, the production was in kilograms.

The analysis of the data obtained was through descriptive analysis, means, maximums, minimums, standard deviation, and frequencies.

\section{Sampling framework}

The localities included in the sampling framework are eight: Las flores, Barrio Juárez, Matías Romero Avendaño, Buenavista, San José de las flores, Barrancones, Colonia Hidalgo and Chahuites, which belong to four municipalities in the state of Oaxaca: El Barrio de la soledad, San Juan Guichicovi, Matías Romero Avendaño and Chahuites.

\section{Definition of the sampling framework}

The honey producers in the study zone were established as the unit of analysis, grouping them by the number of beehives that they work with, given that this has a direct relation with the way of trading the product.

When identifying the agents and trading channels, it could be observed that:

a) Small-scale producers ( 1 to 35 beehives) sell the product themselves in the region's market.

b) Medium-scale producers (36 to 150 beehives) use two channels to sell their product, one is the direct sale in the regional market and the other is selling to honey trading companies.

c) Large-scale producers (151 to 500 beehives) sell the totality of their production to trading companies through purchase-sale contracts 
es la venta directa en el mercado regional y la otra es vendiendo a empresas comercializadoras de miel.

c) Los grandes productores (151 a 500 colmenas) venden la totalidad de su producción a empresas comercializadoras mediante contratos de compra venta que les permite recibir pagos adelantados, equipo a crédito, mejorar la infraestructura de producción y acceder a tecnologías que permiten aumentar la eficiencia.

La muestra consideró el agrupamiento de los apicultores en tres estratos de acuerdo al número de colmenas que maneja.

\section{Resultados y Discusión}

El capital en la producción apícola se definió como el conjunto de las herramientas y equipos con que cuenta la unidad de producción y que son destinados a la producción de miel, más el total de colmenas que componen el módulo productivo (Cuadro 2).

Cabe aclarar que cuando se tiene solamente una colmena se dispone del mismo equipo de trabajo (velo, guante, overol, cuña y ahumador) que si se tuviesen dos o más, por lo que la inversión total es la misma en este rubro; sin embargo, en el equipo de extracción sí varía. Un mayor número de colmenas implica equipos de mayor capacidad. Adicionalmente, la inversión varía de si se usan extractores manuales $\mathrm{u}$ otros que emplean motores con bomba y que envían la miel a un tanque de sedimentación. Otro aspecto de importancia que explica la diferencia en inversión es la calidad del equipo; por ejemplo, un extractor de acero inoxidable para cuatro bastidores tiene un valor casi cuatro veces superior al de acero galvanizado. that allow them to receive advance payments, equipment with credit, to improve the production infrastructure, and to gain access to technologies that allow increasing the efficiency.

The sample considered the grouping of honey producers into three strata according to the number of beehives that they manage.

\section{Results AND Discussion}

The capital in honey production was defined as the set of tools and equipment which the production unit has, and which are destined to honey production, plus the total number of beehives that make up the productive module (Table 2 ).

It should be clarified that when there is only one beehive, the same work equipment is used (vail, glove, overall, wedge and smoker) than if they had two or more, so the total investment is the same in this area; however, the extraction equipment does vary. A larger number of beehives imply equipment of higher capacity. In addition, the investment varies if manual extractors are used or others that use pump motors and which send honey to a sedimentation tank. Another important aspect that explains the difference in investment is the quality of the equipment; for example, a stainless steel extractor for four frames has a value almost four times higher than the galvanized steel one.

\section{Structure of the production cost}

The percentage structure of the honey production costs in México is composed mainly by the variable cost (Magaña, 2010). In this study the variable costs represent $65 \%, 73 \%$ and $70 \%$ for the small-scale, medium-scale and large-scale stratum, respectively (Figure 1). These costs correspond to food,

Cuadro 2. Inversión realizada por estrato según rubro de interés.

Table 2. Investment carried out per stratum according to area of interest.

\begin{tabular}{lcccrr}
\hline Estrato & $\begin{array}{c}\text { Apicultores por } \\
\text { Estrato }\end{array}$ & $\begin{array}{c}\text { Número promedio } \\
\text { de colmenas }\end{array}$ & $\begin{array}{c}\text { Inversión en } \\
\text { colmenas }(\$)\end{array}$ & $\begin{array}{c}\text { Equipo de } \\
\text { protección }(\$)\end{array}$ & $\begin{array}{c}\text { Total de } \\
\text { inversión }(\$)\end{array}$ \\
\hline Pequeńo & 6 & 23 & $\$ 28389.00$ & $\$ 1045.00$ & $\$ 29434.00$ \\
Mediano & 11 & 105 & $\$ 126545.00$ & $\$ 1367.00$ & $\$ 127912.00$ \\
Grande & 6 & 283 & $\$ 377778.00$ & $\$ 5502.00$ & $\$ 383280.00$ \\
\hline
\end{tabular}

Fuente: elaboración propia con datos de la encuesta a productores, 2013. \&ource: authors' elaboration with data from the survey to producers, 2013. 


\section{Estructura del costo de producción}

La estructura porcentual de los costos de producción de la miel en México se compone mayoritariamente por el costo variable (Magaña, 2010). En el presente estudio los costos variables representan $65 \%$, $73 \%$ y $70 \%$ para el estrato pequeńo, mediano y grande, respectivamente (Figura 1). Dichos costos corresponden a alimentación, medicamentos, mantenimiento de colmenas (reparación de bastidores, alzas, cámara de cría, pisos y tapas), clavos, alambre, mano de obra, gasolina y mantenimiento de vehículo.

En el caso de los costos fijos se consideran rubros tales como: sala de extracción, vehículos, pago de salarios en caso que haya nómina, pago de luz, renta de terreno y depreciación de equipo. Aunque en el estrato pequeño porcentualmente presentan los costos más altos comparados a los otros dos estratos, los productores de miel buscan optimizar sus recursos mediante la adquisición de su propia tecnología, procreación de sus propias abejas reinas, y reuso de insumos, tales como la cera al utilizar su propio equipo.

A continuación se resaltarán aquellos rubros más importantes de los costos variables, lo que permite determinar la rentabilidad de la actividad apícola. medicines, beehive maintenance (repairing frames, lifts, offspring chambers, floors and lids), nails, wire, workforce, gasoline, and vehicle maintenance.

In the case of the fixed costs, aspects such as the following are considered: extraction rooms, vehicles, salary payment in case there are wages, electricity bill, land rental and depreciation of equipment. Although the highest costs in percentage are present in the small-scale stratum compared to the other two strata, the honey producers seek optimizing their resources through the acquisition of their own technology, procreation of their own queen bees, and reuse of inputs, such as wax to use their own equipment.

Next the most important areas of the variable costs are highlighted, which allows determining the profitability of the apiculture activity.

The cost structure of the total production of honey (Table 3) in the study region of the Tehuantepec Isthmus, the relative participation of the expenditure to purchase sugar required for the larger producer to feed the beehives with fructose or honey from the wax (the honey that is left over on the wax dripping after the desoperculation), and other practice transhumance (they move the beehives once the flowering is over, thus decreasing the artificial feeding, although the costs are increased

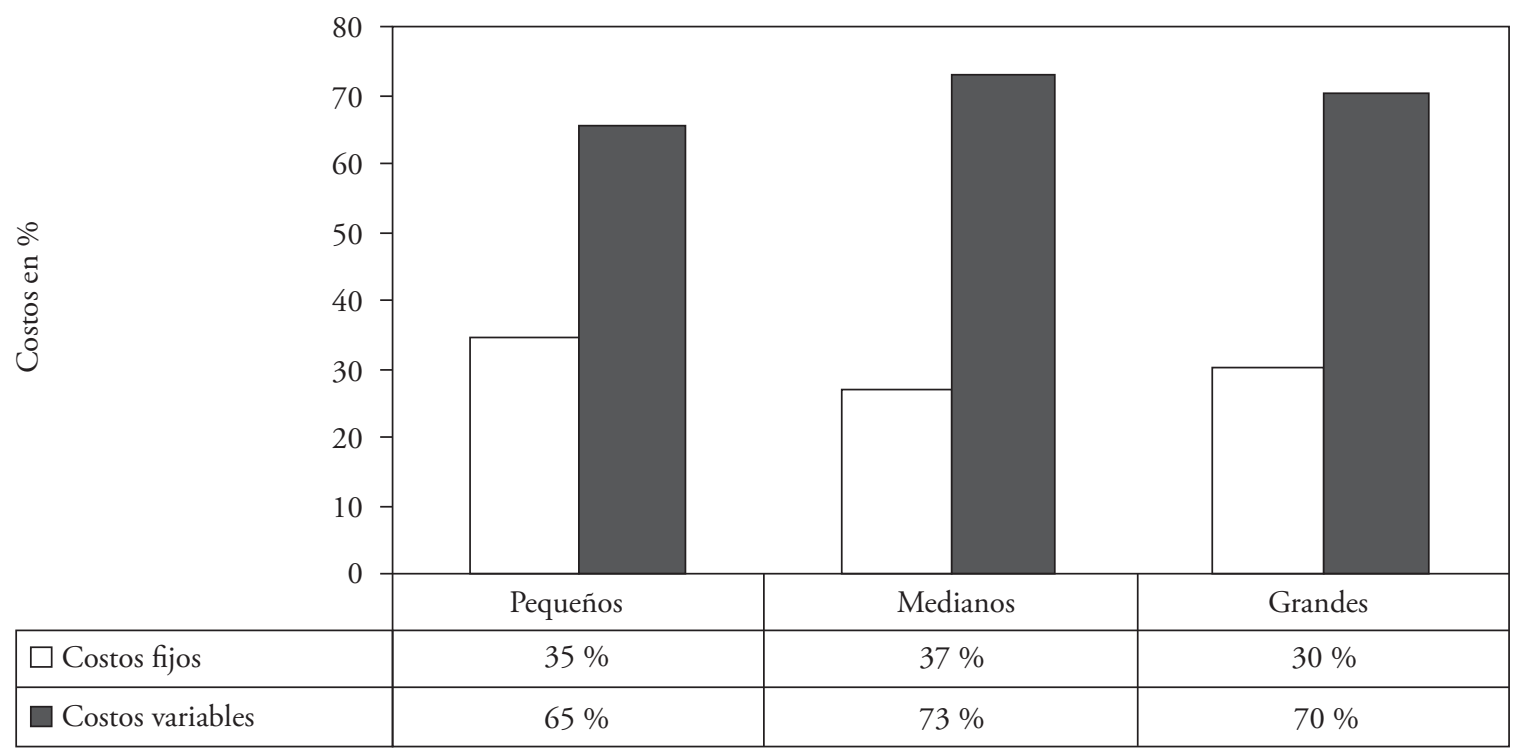

Fuente: elaboración propia con datos de la encuesta a productores, 2013. Source: authors' elaboration with data from the survey to producers, 2013.

Figura 1. Estructura porcentual del costo de producción de miel.

Figure 1. Percentage structure of the honey production cost. 
La estructura del costo de producción total de la miel (Cuadro 3) en la región de estudio del Istmo de Tehuantepec, la participación relativa de las erogaciones en la compra de azúcar precisó que el productor mayor alimenta las colmenas con fructuosa o con miel de la cera (la miel que le queda a la cera escurriendo después de la desoperculación) y otros practican la trashumancia (mueven las colmenas de lugar cuando ya terminó la floración, así disminuyen la alimentación artificial, aunque se incrementan los costos por concepto de flete y mano de obra pero, por otro lado, implementan una economía de escala).

Por otra parte, en el rubro de medicamentos contra plagas, una de las enfermedades, como la Varroa Destructor (ácaro parásito de la abeja Apis mellifera) y las hormigas, es un problema importante para atender en el rubro económico, lo que provoca disminución de ingresos en el bolsillo del productor.

En el rubro de la cera, los apicultores del estrato de mayores colmenas invierten en equipos para estampar la cera, a diferencia de los pequeños que la envían a estampar, esto porque con una producción pequeña no es costeable comprar ese equipo y generalmente from freight and workforce, but on the other hand, they implement an economy of scale).

On the other hand, in the area of drugs against pests, one of the diseases, the Varroa Destructor (parasite mite of the bee Apis mellifera and ants), is an important problem to address in the economic aspect, causing a decrease in income for the producer's pocket.

In the aspect of the wax, honey producers of the stratum of more beehives invest in equipment to stamp the wax, in contrast with the small-scale producers who send it to be stamped, this because with small-scale production it is not affordable to purchase this equipment and they generally send it to be processed with large-scale honey producers, or else, they buy it already stamped.

One of the variable costs that impact the expenditures of the honey producer is fuel, the daily use in the activity mainly in the vehicle with $18 \%, 21 \%$ and $27 \%$ in the small-scale, mediumscale and large-scale strata. It can be compared with beehive maintenance (nail, wire, frame repair) which represent $1 \%, 1 \%$ and $0.40 \%$ in the small-scale, medium-scale and large-scale strata.

Cuadro 3. Estructura de los costos de producción y rentabilidad de la actividad apícola por estrato (\$). Table 3. Structure of production costs and profitability of the apiculture activity per stratum (\$).

\begin{tabular}{|c|c|c|c|c|c|c|}
\hline Conceptos & Pequeño & $\%$ & Mediano & $\%$ & Grande & $\%$ \\
\hline Azúcar & 1947.50 & 15.415 & 6412.7 & 11.211 & 8000.0 & 5.586 \\
\hline Medicamentos & 800.00 & 6.36 & 3930.0 & 6.97 & 7000.0 & 4.885 \\
\hline Cera & 460.00 & 3.64 & 1345.5 & 2.42 & 1291.7 & 0.901 \\
\hline Combustible & 2333.33 & 18.518 & 11872.7 & 20.821 & 39204.0 & 27.3427 \\
\hline Subtotal & 5540.83 & 0.8 & 23560.9 & 0.6 & 55495.7 & \\
\hline $\begin{array}{l}\text { Mantenimiento de colmena } \\
\text { (clavos, alambre, bastidores) }\end{array}$ & 103.33 & 0.81 & 346.4 & 0.61 & 587.0 & 0.41 \\
\hline Subtotal & 103.33 & 2.1 & 346.4 & 0.8 & 587.0 & \\
\hline Mano de obra(personal) & 1440.00 & 11.4 & 9396.0 & 16.4 & 39204.0 & 27.34 \\
\hline compra de reinas & 900.00 & 7.1 & 8100.0 & 14.2 & 4666.7 & 3.25 \\
\hline Subtotal & 900.00 & 3.67 & 8100.0 & 2.414 & 4666.7 & 27.343 \\
\hline Total Costos Variables $(\$)$ & 8254.17 & 65.465 & 41853.3 & 73.273 & 100553.3 & 70.1270 \\
\hline \multicolumn{7}{|c|}{ Costo Fijo } \\
\hline Costos fijos de operación & 150.00 & 1.21 & 180.00 & 0.31 & 1000.00 & 0.701 \\
\hline Depreciación de activos fijos & 4210.07 & 33.433 & 15117.49 & 26.526 & 41849.51 & 29.1829 \\
\hline Total costo fijo $(\$)$ & 4360.07 & 34.635 & 15297.49 & 26.827 & 42849.51 & 29.8830 \\
\hline Costo total de producción & 12614.20 & 100.00 & 57150.76 & 100.00 & 143402.84 & 100.00 \\
\hline Total de ingresos & 33959.00 & & 149080.92 & & 396038.97 & \\
\hline Rentabilidad & 21344.80 & & 91930.16 & & 252636.13 & \\
\hline
\end{tabular}

Fuente: Elaboración propia con datos de la encuesta a productores, 2013. Source: authors' elaboration with data from the survey to producers, 2013.

Nota: en el análisis no está tomado en cuenta los costos de desgaste de vehículo, infraestructura y en su caso renta de terreno ${ }^{4}$. Note: the analysis does not include the costs of vehicle wear, infrastructure, and if the case may be, land rental ${ }^{4}$. 
la mandan a maquilar con los grandes apicultores, o bien, la compran ya estampada.

Uno de los costos variables que impactan en los egresos del apicultor es el combustible, el uso cotidiano en la actividad principalmente en el vehículo con $18 \%, 21 \%$, y $27 \%$ estrato pequeño, mediano y grande. Se puede contrastar con el mantenimiento de colmenas (clavo, alambre, y reparación de bastidor) que representan $1 \%, 1 \%$ y $0.40 \%$ en los estratos pequeño, mediano y grande.

El pago de la mano de obra, la erogación hecha representa la principal en el rubro de los costos variables y se debe a que los apicultores tienen la necesidad de contratar mano de obra para la realización de las diversas actividades en el apiario; de esta la principal es la cosecha.

Cabe resaltar que el estrato grande tiende a hacer sus propias abejas reinas, lo que hace que sustituya la compra y disminuya sus costos variables, a diferencia del estrato pequeño que tiene que comprarlas, o algunos productores realizan divisiones de sus colmenas y dejan que la abeja críen sus propias reinas, lo cual ocasiona reinas de baja calidad genética y alta africanización.

Por su parte, la magnitud del costo fijo de producir miel con respecto al del total de la producción representa aproximadamente $35 \%$, $27 \%$ y $30 \%$ respectivamente, para el productor pequeño, mediano y grande del total de los costos. Esto refleja que el estrato pequeño con extractor de acero inoxidable de grado alimenticio eleva por cuatro veces los costos fijos en relación con sus costos totales. Dentro de las tres principales erogaciones del citado costo, el más importante fue el valor de la depreciación en equipos; el de la depreciación de los vehículos de transporte propiedad del apicultor no está incluido en los costos, lo que podría reducir la rentabilidad de los apicultores.

\section{Ingreso por venta de productos de la colmena}

Un aspecto importante del análisis del ingreso es el destino de la producción; se observa que los productores que están en el estrato grande tienen mayor ingreso. $\mathrm{El}$ ingreso total por venta de miel en el estrato 1 fue de $\$ 33$ 959.00; en el 2, de $\$ 149$ 081.00; y en el 3, de $\$ 396$ 039.00. La relación obedece al canal de comercialización del productor y del valor agregado que le dé a su producto, además de que tienen mayor rendimiento por colmena $39.7 \mathrm{~kg} /$ colmena en
In payment for the workforce, the expenditure made represents the main one in the area of variable costs and it is because honey producers have the need to hire workforce to carry out the various activities in the apiary; of these, the main one is the harvest.

It should be highlighted that the large-scale stratum tends to make its own queen bees, which causes them to substitute the purchase and decrease its variable costs, compared to the small-scale stratum that has to buy them, or the case of some producers who divide their beehives and let the bees breed their own queens, which produces queens of low genetic quality and high africanization.

In turn, the magnitude of the fixed cost of producing honey with regards to the total production represents approximately $35 \%, 27 \%$ and $30 \%$, respectively, for the small-scale, medium-scale and large-scale producer of the total costs. This reflects that the small-scale stratum with food grade stainless steel extractor increases four-fold the fixed costs in comparison to the total costs. Within the three main expenditures of this cost, the most important one was the depreciation value of equipment; that of depreciation of the transport vehicles that belong to the beekeeper is not included in the costs, which could reduce the profitability of the honey producers.

\section{Income from the sale of beehive products}

An important aspect of the income analysis is the destination of the production; it is observed that the producers who are in the large-scale stratum have a higher income. The total income from honey sales in stratum 1 was $\$ 33$ 959.00; in 2, \$149 081.00; and in 3, \$396 039.00. The relation responds to the commercialization channel of the producer and the added value he gives his product, in addition to having a higher yield per beehive, of $39.7 \mathrm{~kg} /$ beehive, compared to the small-scale stratum where they produce in average $38.3 \mathrm{~kg} /$ beehive and the medium-scale stratum, of $36.5 \mathrm{~kg} /$ beehive.

Currently the income that is obtained from apiculture is solely from honey sales. However, there is a potential that is not being exploited, for example, with the sale of other products from the beehive, such as royal jelly, pollen, propolis, and the sale of nuclei that would allow the producer to generate other income. The productive diversification is limited to honey and wax, which is employed in the substitution 
comparación con el estrato pequeño que producen en promedio $38.3 \mathrm{~kg} /$ colmena y el estrato mediano $36.5 \mathrm{~kg} /$ colmena.

Actualmente el ingreso que se obtiene en la actividad apícola solo es por la venta de miel. Sin embargo, hay un potencial que no se está explotando, por ejemplo, con la venta de otros productos de la colmena, como jalea real, polen, propóleos, y la venta de núcleos que permitiría al productor generar otros ingresos. La diversificación productiva se limita a miel y cera, la cual es empleada en la sustitución de los panales viejos $\mathrm{y}$ no es una fuente secundaria de ingresos.

El estrato pequeńo tiene un mejor precio por kilogramo (\$47.00), debido a la venta directa al consumidor final, lo que representa la mejor opción por precio comercial que realizan los apicultores. Es claro que el mercado local no tiene la capacidad de compra que tiene el regional, estatal, nacional o a la exportación, por lo que el apicultor se ve obligado a entregar su producción al intermediario, aunque sea a menor precio, que se paga cuando la miel se vende a granel tasada en kg. En el estrato mediano: el precio es de $\$ 45.90$ por $\mathrm{kg}$. En este estrato la producción es destinada principalmente al acopiador, quien la envía a la exportación y otro porcentaje lo absorbe el mercado regional a un precio mayor al menudeo.

En el estrato grande el precio promedio es el menor $(\$ 41.80)$ que tienen los productores debido a que tienen sobreproducción y el mercado regional o estatal no lo absorbe; lo entregan por barril de $300 \mathrm{~kg}$, lo que da la ventaja de tener concertada su producción desde antes de la cosecha, y tienen definido su canal de comercialización con el intermediario denominado acopiador quien compra toda la producción, pero a un menor precio. En 2013 el kilogramo de miel tuvo un precio de $\$ 38.11$ (SIAP, 2013).

Sin embargo, hay otros productores en la región de estudio del estrato grande que tienen su canal de comercialización con marca propia, etiquetado y venden directamente a centros comerciales a un mejor precio, evitando así al intermediario.

Es importante mencionar que aunque en promedio el estrato pequeño tiene un precio más alto, el grande tiene una mayor rentabilidad debido a varios factores que están asociadas, como la economía de escala, los canales de comercialización y, en algunos casos, cuando el productor le da el valor agregado invirtiendo en una marca, envasado y etiquetado para ofrecerlo a los centros comerciales. of old honeycombs and is not a secondary source of income.

The small-scale stratum has a better price per kilogram (\$47.00), due to the direct sale to the final consumer, which represents the best option in commercial price that the beekeepers obtain. It is clear that the local market does not have the purchasing capacity that the regional, state, national or exports does, so the producer is forced to hand over his production to the intermediary, even if it is at a lower price, paid when the honey is sold in bulk valued in $\mathrm{kg}$. In the small-scale stratum, the price is $\$ 45.90$ per $\mathrm{kg}$. In this stratum the production is destined primarily to the middle men, who send it to exports, and another percentage is absorbed by the regional market at a higher price in retail.

In the large-scale stratum the average price is the lowest $(\$ 41.80)$ which producers get because they have overproduction and the regional or state market does not absorb it; they deliver it in barrels of $300 \mathrm{~kg}$, which gives the advantage of having their production concerted since before the harvest, and their commercialization channel is defined with the intermediary called middle man who buys all of the production, but at a lower price. In 2013 the kilogram of honey had a price of $\$ 38.11$ (SIAP, 2013).

However, there are other producers in the study region of the large-scale stratum who have their trading channel with a brand of their own, labelled and sold directly to commercial centers at a lower price, thus avoiding the intermediary.

It is important to mention that although in average the small-scale stratum gets a higher price, the large-scale one has a higher profitability due to several associated factors, such as the economy of scale, the commercialization channels and, in some cases, when the producer gives it the added value by investing in a brand, packaging and labelling to offer it to commercial centers.

\section{Point of equilibrium}

Horngreen (2007) explains that the point of equilibrium is the amount of production sold at which the total income is equal to the total costs; that is, the operative profit is zero. The point of equilibrium indicates the magnitude of production required to be sold to avoid a loss. 


\section{Punto de equilibrio}

Horngreen (2007) explica que el punto de equilibrio es la cantidad de producción vendida en la que el total de ingresos es igual al total de costos; es decir, la utilidad operativa es cero. El punto de equilibrio indica la magnitud de la producción que se requiere vender para evitar una pérdida.

El punto de equilibrio del estrato pequeño amerita atención en particular porque una de las hipótesis es si la implementación de colmenas en baja escala es una alternativa viable que tendrá un impacto positivo en el nivel de vida del productor mediante la generación de empleo e ingresos adicionales en su unidad de producción. El punto de equilibrio para el pequeño productor en una situación en que no pierde ni gana es de \$5760.15 M.N (cinco mil setecientos sesenta pesos y quince centavos), ingreso que puede obtener con la venta de 144.18 kilogramos de miel al precio de $\$ 47.00$ pesos porque se consideran costos que incluyen al consumidor final como la compra del envase, etiqueta, según el caso, trabajos de difusión, tiempo, y al producto se le aporta un valor agregado; en algunos casos lo vende no como alimento sino como un producto medicinal (Figura 2).

Si 38 kilos se toman como la producción promedio por colmena, dato que fue tomado de la encuesta a productores de la Región del Istmo de Tehuantepec y que está por arriba de la media nacional de $31.5 \mathrm{~kg} /$ colmenas (SAGARPA, 2010), el punto de equilibrio se alcanzaría con una producción total de 144.18 kilogramos, lo cual es factible lograr con cuatro colmenas.

Los costos fijos también varían de acuerdo con la capacidad de instalación de la planta, pero estos no influyen en el volumen de producción, por lo que se debe buscar sean menores para que se alcance más rápido el punto de equilibrio. Para que los productores lleguen al nivel de producción en que son exactamente iguales los ingresos por ventas, a la suma de los costos fijos y variables es importante trabajar al $100 \%$ de la capacidad de los costos fijos (extractores, vehículos, sala de extracción, salarios), lo que permitirá tener una mayor rentabilidad.

La relación beneficio/costo indica que en la apicultura por cada peso invertido (costo variable y fijo) se obtiene una rentabilidad de 92 centavos en el estrato pequeño, en el mediano es de 96 centavos y en el grande, de 1.01 en 2013. Este indicador es
The point of equilibrium of the small-scale stratum deserves attention in particular because one of the hypotheses is that the implementation of beehives at a small scale is a viable alternative which will have a positive impact on the standard of living of the producer through employment generation and additional income in his production unit. The point of equilibrium for the small-scale producer in a situation in which he doesn't win or lose is $\$ 5760.15$ pesos, income that he can obtain with the sale of 144.18 kilograms of honey at a price of $\$ 47.00$ pesos because these are considered costs that include the final consumer, such as the purchase of container, label, depending on the case, dissemination work, time, and the product is given an added value; in some cases it is sold not as food but rather as a medicinal product (Figure 2).

If 38 kilograms are taken as the average production per beehive, piece of data that was taken from the survey with producers of the Tehuantepec Isthmus Region, and this is above the national mean of $31.5 \mathrm{~kg} /$ beehive (SAGARPA, 2010), the point of equilibrium would be reached with a total production of 144.18 kilograms, which is feasible to achieve with four beehives.

The fixed costs also vary depending on the installation capacity of the plant, but these do not influence the production volume, so it should be sought for them to be smaller for the point of equilibrium to be reached faster. For the producers to reach the production level at which the incomes over sales are exactly equal to the sum of fixed and variable costs, it is important to work at $100 \%$ of the capacity of the fixed costs (extractors, vehicles, extraction room, wages), which would allow having a higher profitability.

The benefit/cost relation indicates that in apiculture for every peso invested (variable and fixed cost), a profitability of 92 cents is obtained in the small-scale stratum, in the medium-scale it is 96 cents, and in the large-scale 1.01, in 2013. This indicator is evidence that apiculture in the study region is profitable, since for each peso invested in the activity the return from an investment equivalent in fixed rent promissory notes of $3.8 \%$ (the promissory note is a document by which the emitting entity is committed to make a payment, at the time of expiration date, in favor of its holder, and involves the payment of interest at expiration), is exceeded. 

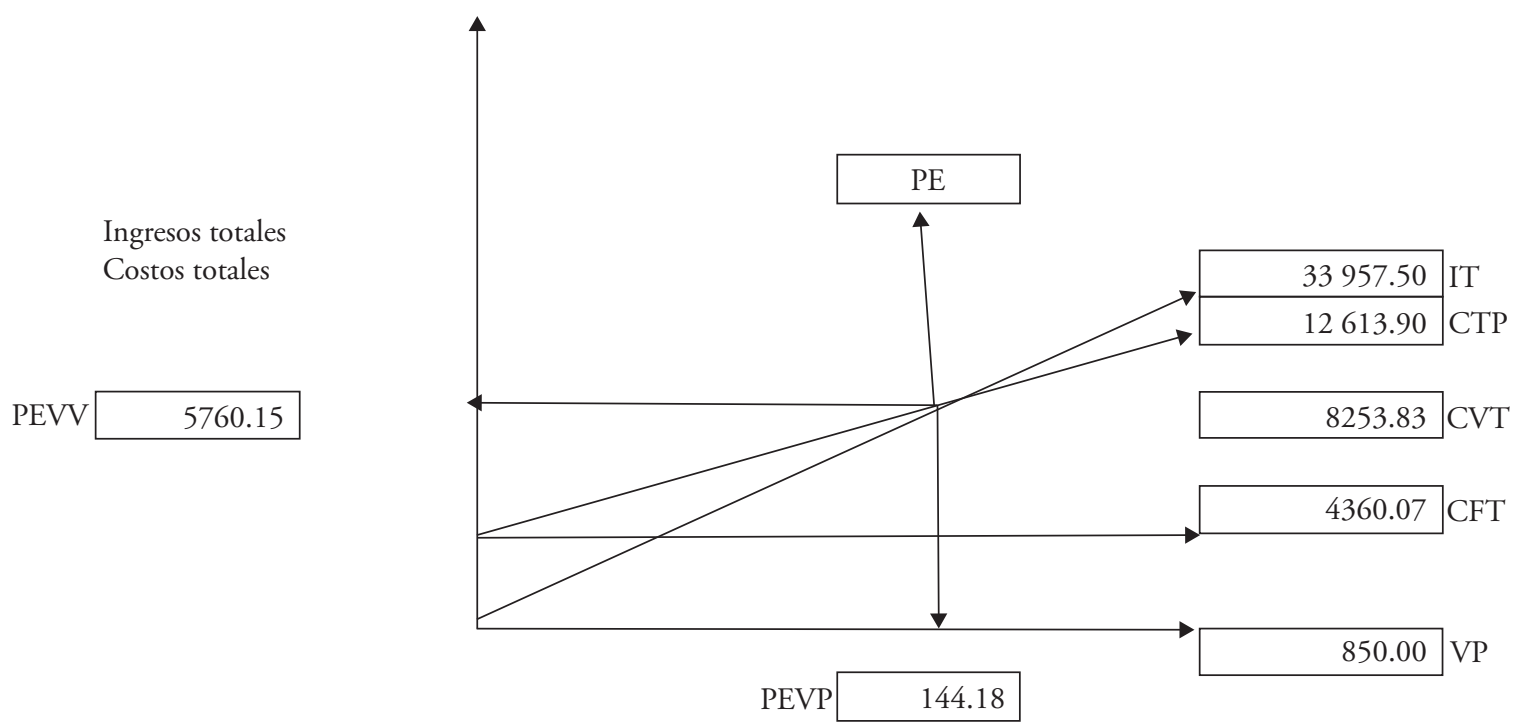

Fuente: elaboración propia con datos de la encuesta a productores, 2013. Source: authors' elaboration with data from the survey to producers, 2013.

Nota: IT: Ingreso Total, CTP: Costo total de producción, CVT: Costo variable total, CFT: Costo fijo total, VP: Valor de la producción, PE: Punto de equilibrio, PEVP: Punto de equilibrio del volumen de producción, PEVV: Punto de equilibrio del volumen de ventas. Note: IT: Total Income, CTP: Total production cost, Total variable cost, Total fixed cost, Production value, PE: Point of equilibrium, PEVP: Point of equilibrium of the production volume, PEVV: Point of equilibrium of the sales volume.

Figura 2. Punto de equilibrio del estrato pequeńo.

Figure 2. Point of equilibrium of the small-scale stratum.

evidencia de que la apicultura en la región de estudio es rentable, pues por cada peso invertido en la actividad se supera el rédito de una inversión equivalente en pagarés de renta fija de $3.8 \%$ (el pagaré es un documento por el que la entidad emisora se compromete a efectuar un pago, a la fecha de vencimiento, en favor del tenedor del mismo, y conllevan la percepción de interés al vencimiento). Si no se invierte en una actividad rentable en un plazo, el dinero de la inversión estará afectado por el proceso inflacionario ocurrido durante ese año y va a perder el poder adquisitivo.

\section{Conclusiones}

En la Región del Istmo de Tehuantepec, la apicultura es una actividad rentable.

La explotación es factible bajo las condiciones técnicas y de mercado.

La rentabilidad en la apicultura está relacionada con el mercado. Es importante tener un canal de comercialización para vender el producto directamente al consumidor. En la presente investigación los productores del estrato pequeño son los que obtiene el
If there is no investment in the profitable activity in a period, the money from the investment will be affected by the inflation process that takes place during that year and the purchasing power will be lost.

\section{Conclusions}

In the Tehuantepec Isthmus Region, apiculture is a profitable activity.

Farming is feasible under the technical and market conditions.

The profitability in apiculture is related to the market. It is important to have a trading channel to sell the product directly to the consumer. In this study the producers from the small-scale stratum are the ones who obtain the highest price in the market. The producers from the medium-scale and largescale strata sell their product through intermediaries, which, although it makes the commercialization of higher volumes of honey possible, results in them getting a lower price.

The small-scale stratum showed that two people are required to manage the beehives, which can be 
mayor precio de mercado. Los productores de los estratos mediano y grande comercializan su producto por medio de intermediarios lo que, aunque facilita la comercialización de mayores volúmenes de miel, hace que reciban un precio menor.

El estrato pequeño mostró que se requieren dos personas para el manejo de las colmenas, las cuales pueden ser familiares para autoempleo al padre o hijos de sexo indistinto, lo que permite mostrar la optimización de los recursos como la mano de obra.

Con base en el promedio de producción por colmenas en la región de estudio, 38 kilos por colmena, el punto de equilibrio se alcanzaría con una producción total de 144.18 kilos, las cuales se obtienen mediante cuatro colmenas. $\mathrm{Al}$ respecto, el único estrato que cumple con esta condición es el estrato pequeño.

Con base en lo anterior, se afirma que las unidades de producción rural pueden diversificar su actividad para complementar sus ingresos a través de la actividad apícola, de acuerdo con los datos obtenidos en campo por los apicultores que viven en la región de estudio muestra que puede ser complementaria bajo las siguientes condiciones: manejar 23 colmenas en promedio en un solo apiario, equipo de extracción de 8 a 24 bastidores, trabajar en grupos de trabajo organizados de apicultores para disminuir costos en mano de obra, capacitación, y en la sala de extracción, pueden dedicar tiempo a su actividad principal y por las tardes o un fin de semana dedicarle tiempo a las colmenas y trabajarlo como un negocio familiar que sirva de autoempleo.

\section{Notas}

${ }^{4} \mathrm{Si}$ se incluyera los costos de renta de terreno, desgaste de vehículo, infraestructura, disminuiría la rentabilidad en la relación beneficio/costo. * If the land rental costs, vehicle wear, and infrastructure were included, the profitability would decrease in the benefit/cost relation.

\section{Literatura Citada}

Bowler, I., G. Clark, A. Crockett, B. Ilbery, and A. Shaw. 1996. The development of alternative farm enterprises: a study of family labour farms in the Northern Pennines of England. In: Journal of Rural Studies. Vol. 12, Núm.3, Julio 1996.

Cajero, Salvador. 2004. Programa de inocuidad y calidad de la miel: Las buenas prácticas de producción de miel. In: Memorias del foro Nacional sobre la cadena de miel Quintana Roo. Quintana Roo. FQROOP. pp: 1-51. family members for self-employment of the father or children of both sexes, which allows showing the optimization of resources such as workforce.

Based on the average production per beehive in the study region, 38 kilograms per beehive, the point of equilibrium would be reached with a total production of 144.18 kilograms, which are obtained through four beehives. In this regard, the only stratum that fulfills this condition is the small-scale stratum.

Based on this, we can affirm that the rural production units can diversify their activity to complement their income through apiculture; according to the data obtained in the field by beekeepers who live in the study region, the activity can be complementary under the following conditions: managing 23 beehives in average in a single apiary, extraction equipment of 8 to 24 frames, working in organized groups of beekeepers to decrease labor costs, training and in the extraction room; they can devote time to their main activity and in the afternoons or weekends devote time to the beehives and work with this as a family business that serves for self-employment.

- End of the English version -

Contreras Suárez, Enrique. 2012. Marginalidad, pobreza y exclusión en América Latina. Continuidades y ruptura entre los años sesenta y los albores del siglo XXI. In: Pobreza, desigualdad y desarrollo, conceptos y aplicaciones. Universidad Autónoma de México. Centro Regional de Investigaciones Multidisciplinarias. Cuernavaca, México.

CONEVAL (Consejo Nacional de Evaluación de la Política de Desarrollo Social). 2012. http://www.coneval.org.mx/ Informes/COMUNICADOS_DE_PRENSA/REFLEXIONES_SOBRE_LA_AUTONOMIA_DEL_CONEVAL.pdf (Mayo de 2014).

CONEVAL (Consejo Nacional de Evaluación de la Política de Desarrollo Social). 2012. Informe de Pobreza 2012. http://www.coneval.org.mx/Informes/Pobreza/Informe\%20de $\% 20$ Pobreza $\% 20$ en\%20Mexico $\% 202012 /$ Informe\%20de\%20pobreza\%20en\%20M\%C3\%A9xico\%20 2012_131025.pdf (abril de 2014).

De Janvry Alain, y Elisabeth Sadoulet. 2004. Hacia un enfoque territorial del desarrollo rural Costa Rica, Universidad de California (Sede de Berkeley). pp: 1-21.

Echazarreta-Gonzalez, C. 1999. Caracterizacion de la apicultura en la península de Yucatán. Memorias del Foro de Proyectos integrales: Sistema Producto Miel, Mérida, Sistema/vady. pp: $29-43$. 
García A., Miguel. 2005. El Megaproyecto del Istmo de Tehuantepec: Globalización y deterioro socio ambiental, FCAUNAM. pp: 1-80.

Godoy Montañez, R. 1999. Apicultura yucateca e identidad de la investigación en la Universidad Autónoma de Yucatán. Memorias del Foro de Proyectos Integrales: Sistema Producto Miel, Mérida, Sisierra/UADY, pp. 12-13.

Gómez, Emanuel. 2005. Diagnóstico regional del Istmo de Tehuantepec, México. Centro de Investigaciones y Estudios Superiores en Antropología Social Unidad Istmo. 119 p.

Hazael, Ceron. 2012. Impactos de la diversificación de fuentes de ingreso en la disminución de la desigualdad de los hogares mexicanos. Revista del CIECAS-IPN. Vol.VIII. Num 28.

Herrera, Fabio. 1994. Fundamentos de Análisis Económico. Costa Rica. Centro Agronómico Tropical de investigación y enseñanza. pp: 1-61.

Horngreen, Charles. 2007. Contabilidad de costos. México, Pearson Educación. pp: 1-350.

INEGI (Instituto Nacional de Estadística y Geografía). 2013. Sistema de Cuentas Nacionales de México, 2013. http:// www.inegi.org.mx/est/contenidos/proyectos/cn/pibt/doc/ scnm_metodologia_01.pd f (mayo de 2014).

López, Juana, Pedro Maldonado, y Véronique Sophie Ávila. 2011. Diversificación económica y desigualdades económicas en el distrito de Ixtlán, Oax. Ciencias Sociales. Vol.3, Num.11.

Magaña, Miguel. 2010. Costos y rentabilidad del proceso de producción apícola en México. Yucatán: Instituto Tecnológico de Conkal. pp: 100-101.

Magaña, Miguel, Yolanda Moguel, Sanginés García, y Carlos Leyva. 2012. Estructura e importancia de la cadena productiva y comercial de la miel en México. Revista Mexicana de Ciencias Pecuarias. Vol.3 No.1.

Martínez, Santos. 2010. Plan Rector Sistema Producto Apícola de Oaxaca. Universidad Autónoma Chapingo. pp:1-59.

Mas, Francisco José. 2010. Temas de investigación comercial. España, Club Universitario. pp: 1-376
Pellens, Tom. 2006. Composición del Ingreso Familiar y la Diversificación Agrícola, Bolivia, Centro De Investigación y Promoción Del Campesinado. pp: 3-87.

Phélinas, Pascale. 2002. Las actividades complementarias de las explotaciones agrícolas peruanas. Bulletin de l'Institut Francais d'Études Andines. Vol. 31, núm. 3.

SAGARPA (Secretaría de Agricultura, Ganadería, Desarrollo Rural, Pesca y Alimentación). 2010. http://www.sagarpa. gob.mx/ganaderia/Publicaciones/Lists/Sistemas\%20Productos\%20Pecuarios/Attachments/24/plan_final.pdf (Abril de 2014).

SAGARPA (Secretaría de Agricultura, Ganadería, Desarrollo Rural, Pesca y Alimentación). 2001. (Organización Nacional de Apicultores) 2001 http://www.sagarpa.gob.mx/ganaderia/ Publicaciones/Lists/Sistemas\%20Productos\%20Pecuarios/ Attachments/24/plan_final.pdf (Abril de 2014).

SAGARPA (Secretaría de Agricultura, Ganadería, Desarrollo Rural, Pesca y Alimentación). 2014. Servicio de Información Agroalimentaria y Pesquera https://www.gob.mx/cms/ uploads/attachment/file/165992/abeja.pdf (Mayo de 2014).

Sands, D. M. 1984. The Mixed subsistence-commercial Production System in the Peasant Economy of Yucatán, México: An Anthropological Study in Commercial Beekeeping. Tesis Doctoral. Faculty of the Graduate School of Cornell University. USA. 551 p.

SIAP (Servicio de Información Agroalimentaria y Pesquera). 2013. http://infosiap.siap.gob.mx/repoAvance_siap_gb/pecAvanceProd.jsp (Abril de 2014).

Valdivia, C., E. Dunna, and C. Jette. 1996. Diversification as a Risk Management Strategy in an Andean Agropastoral Community. American Journal of Agricultural Economics, Vol. 78, No. 5.

Yúnez-Naude, and Taylor Edward. 2001. The Determinants of Nonfarm Activites and Incomes of Rural Housholds in México, with Emphasis on Education. In: World Development. Vol. 29, Núm. 3.

Villanueva, G., y Collí Ucán. 1996. La apicultura en la Península de Yucatán, México, y sus perspectivas. Folia Entomológica Mexicana, núm. 97. pp: 55-70. 